\title{
PENGARUH PENGGUNAAN TEPUNG Azolla microphylla FERMENTASI PADA PAKAN TERHADAP BOBOT DAN PANJANG SALURAN PENCERNAAN AYAM KAMPUNG PERSILANGAN \\ (Effect Of The Use Of Azolla Microphylla Fermentation Powder Feed On Weight And Length Digestive Tract Of Crossbreed Native Chicken)
}

\author{
F. Amalia, R. Muryani dan Isroli \\ Program Studi S1 Peternakan \\ Fakultas Peternakan dan Pertanian Universitas Diponegoro, Semarang \\ Email: firfirdaamalia@gmail.com
}

\begin{abstract}
ABSTRAK
Penelitian ini bertujuan untuk mengevaluasi penggunaan tepung Azolla microphylla terfermantasi terhadap bobot dan panjang saluran pencernaan ayam kampung persilangan. Penelitian ini menggunakan 80 ekor ayam kampung persilangan ayam Bangkok dan Lohman 202 dengan bobot badan 469,80 \pm 38 gram $(\mathrm{CV}=3,33 \%)$. Bahan pakan yang digunakan yaitu jagung, bungkil kedelai, tepung ikan, pollard, bekatul, $\mathrm{CaCO}_{3}$, premix dan tepung azolla fermentasi. Perlakuan yang diterapkan adalah tepung Azolla microphylla fermentasi $0 \%$ (T0), 10\% (T1), 15\% (T2) dan 20\% (T3). Kandungan protein pakan $17 \%$ dan energi metabolisme $2800 \mathrm{kkal} / \mathrm{kg}$. Penelitian menggunakan Rancangan Acak Lengkap (RAL) dengan 4 perlakuan dan 4 ulangan. Parameter yang diamati adalah bobot dan panjang saluran pencernaan ayam kampung persilangan. Data dianalisis dengan analisis ragam. Hasil penelitian menunjukkan bahwa Azolla microphylla fermentasi berpengaruh terhadap bobot ileum dan panjang sekum saluran pencernaan ayam kampung persilangan. Kesimpulan dari penelitian ini adalah Penggunaan tepung Azolla microphylla fermentasi menurunkan bobot ileum dan meningkatkan panjang sekum saluran pencernaan ayam kampung persilangan.
\end{abstract}

Kata kunci : Ayam Kampung Persilangan, Saluran Pencernaan, Tepung Azolla microphylla fermentasi

\begin{abstract}
The purpose of study were to evaluate the use of Azolla microphylla fermentation powder on weight and length the gastrointestinal tract crossbreed native chicken. This study used 80 chickens Bangkok and Lohman chicken cross weighing $202 \pm 38$ grams 469.80 (CV = 3.33\%). Feed materials used such as corn, soybean meal, fish meal, wheat pollard, rice bran, CaCO3, premix and Azolla fermentation powder. The treatment applied are Azolla microphylla fermentation powder 0\% (T0), 10\% (T1), 15\% (T2) and 20\% (T3). Feed protein content $17 \%$ and energy metabolism $2800 \mathrm{kcal} / \mathrm{kg}$. Research use completely randomized design (CRD) with 4 treatments and 4 replications. Parameters measured were the weight and length of the gastrointestinal tract of crossbreed native chicken. Data were analyzed by analysis of variance. The results showed that significant effect $(P>0.05)$ on ileum weight and cecum length crossbreed native chicken the gastrointestinal tract. The
\end{abstract}


conclusion of this study is the use of Azolla microphylla fermentation powder decrease weight of the ileum and increase cecum length crossbreed native chicken the gastrointestinal tract.

Keywords : Crossbreed Native Chicken, Gastrointestinal, Azolla microphylla fermented Powder

PENDAHULUAN

Ayam kampung merupakan ternak unggas yang kehidupannya sudah dekat dengan masyarakat. Produktivitas ayam kampung yang rendah menyebabkan pasokan daging juga rendah. Masyarakat menciptakan berbagai cara untuk meningkatkan produktivitas ayam kampung dengan menyilangkan ayam jantan lokal dengan ayam ras betina sehingga menghasilkan ayam kampung persilangan. Ayam kampung persilangan memliki daya adpatasi yang tinggi yaitu mampu menyesuaikan diri dengan kondisi lingkungan, situasi serta perubahan iklim. Ciri-ciri ayam kampung persilangan bertubuh besar sehingga berat tubuhnya lebih tinggi serta pertumbuhannya lebih cepat dibanding ayam kampung lainnya.

Azolla microphylla memiliki kandungan serat kasar tinggi mencapai 23\% (Analisis Proksimat, 2017). Serat kasar yang tinggi menjadi kendala untuk memanfaatkan sebagai bahan pakan ternak unggas karena unggas hanya memiliki sistem pencernaan tunggal sehingga tidak dapat menghasilkan enzim selulase yang mampu mencerna serat kasar. Sebelum azolla diolah untuk dijadikan ransum terlebih dahulu difermentasi untuk menurunkan serat kasar, sehingga dapat meningkatkan kecernaannya. Cara menurunkan kandungan serat kasar dari Azolla microphylla dengan cara memanfaatkan aktivitas mikrobia melalui proses fermentasi.
Saluran pencernaan ayam kampung persilangan berkembang sesuai morfologis dan fisiologis melalui pertambahan umur ayam. Faktor yang mempengaruhi perkembangan saluran pencernaan adalah kualitas dan kuantitas pakan yang dikonsumsi. Pakan yang memiliki serat kasar yang tinggi berpengaruh pada perkembangan saluran pencernaan sehingga akan terjadi perubahan bobot maupun panjang saluran pencernaan (Sturkie, 1976). Serat kasar yang tinggi mampu menentukan perkembangan saluran pencernaan sehingga berpengaruh terhadap peningkatan kinerja saluran pencernaan. Semakin tinggi banyak jumlah ransum yang dikonsumsi maka semakin aktif kinerja usus untuk mencerna pakan sehingga merangsang pertumbuhan organ saluran pencernaan.

Penelitian ini bertujuan untuk mengevaluasi penggunaan tepung Azolla microphylla fermentasi mampu berpengaruh terhadap bobot dan panjang saluran pencernaan. Manfaat dari penelitian ini yaitu memperoleh informasi tentang pengaruh pemberian tepung Azolla microphylla terfermentasi terhadap bobot dan panjang saluran pencernaan ayam kampung persilangan.

\section{MATERI DAN METODE}

Penelitian dengan Judul "Bobot dan panjang relatif saluran pencernaan dengan penggunaan tepung Azolla microphylla fermentasi pada pakan" dilaksanakan pada bulan Desember 2016 - Februari 2017 di 
Laboratorium Ternak Unggas Fakultas Peternakan dan Pertanian, Universitas Diponegoro, Semarang.

Materi yang digunakan dalam penelitian meliputi ayam kampung persilangan antara ayam Bangkok (Ayam lokal) dengan Lohman 202 (ayam ras petelur) dari Peternakan Rakyat di Desa Danurejo Kecamatan Kedu, Temanggung sebanyak 80 ekor umur 4 minggu dengan bobot rata-rata 469,80 $\pm 38 \mathrm{~g}(\mathrm{CV}=3,33 \%)$. Kandungan nutrisi tepung Azolla microphylla (TA) dan tepung Azolla microphylla fermentasi

(TAF) menggunakan EM4.

Alat yang digunakan adalah timbangan, kandang yang dilengkapi dengan tempat pakan dan minum, termometer dan higrometer, pita ukur untuk mengukur saluran pencernaan dan timbangan analitik untuk menimbang saluran pencernaan. Bahan pakan yang digunakan untuk menyusun ransum terdiri atas jagung, bekatul, premix, pollard, tepung ikan, bungkil kedelai, $\mathrm{CaCO}_{3}$ dan tepung Azolla microphylla. Tepung azolla diberikan perlakuan T0, T1, T2, T3 masing -masing 0\%, 10\%, 15\%, dan $20 \%$ di dalam ransum.

Metode yang digunakan yaitu pengambilan secara acak 16 ekor ayam kampung persilangan dari masing-masing unit percobaan pada akhir pemeliharaan umur 11 minggu, Sebelumnya dipuasakan selama kurang lebih 3 jam, ayam kemudian dipotong untuk dilakukan penimbangan bobot dan panjang saluran pencernaannya. Saluran pencernaan yang diukur dimulai dari proventikulus, ventrikulus, usus kecil, yang terdiri dari duodenum, jejunum dan ileum, sekum dan usus besar.

Data dianalisis ragam atau analisis of variance (anova) dengan uji $F$ untuk mengetahui pengaruh perlakuan. Apabila ada pengaruh perlakuan dilanjutkan uji wilayah ganda Duncan.

Tabel 1. Kandungan Nutrisi Azolla microphylla Sebelum dan Sesudah Fermentasi

\begin{tabular}{|c|c|c|c|c|c|c|}
\hline Bahan Pakan & EM (kkal/kg) & PK (\%) & LK (\%) & SK (\%) & $\mathrm{Ca}(\%)$ & $\mathrm{P}(\%)$ \\
\hline $\mathrm{TA}$ & $2849,60^{\mathrm{a}}$ & $26,18^{\mathrm{a}}$ & $2,08^{\mathrm{a}}$ & $23,16^{\mathrm{a}}$ & $1,63^{b}$ & $0,56^{\mathrm{b}}$ \\
\hline $\mathrm{TAF}^{\mathrm{a}}$ & $25338,09^{\mathrm{c}}$ & $24,33^{\mathrm{a}}$ & $3,11^{\mathrm{a}}$ & $23,84^{\mathrm{a}}$ & & \\
\hline $\begin{array}{l}\text { : a. } \\
\quad \text { b. } \\
\text { c. }\end{array}$ & $\begin{array}{l}\text { Hasil Analisis pro } \\
\text { Diponegoro, Semar } \\
\text { Lab Balitnak Bogor } \\
\text { Hasil Perhitungan b }\end{array}$ & $\begin{array}{l}\text { at Labc } \\
\text { 2017). } \\
\text { ar, S. 20 } \\
\text { arkan R }\end{array}$ & Balton. & Nutrisi Te & dan Paka & Universitas \\
\hline
\end{tabular}

Tabel 2. Kandungan Nutrisi Bahan Pakan

\begin{tabular}{lcccccc}
\hline \hline Bahan Pakan & $\begin{array}{c}\mathrm{EM} \\
(\mathrm{kkal} / \mathrm{kg})\end{array}$ & $\begin{array}{c}\text { PK } \\
(\%)\end{array}$ & $\begin{array}{c}\text { LK } \\
(\%)\end{array}$ & $\begin{array}{c}\text { SK } \\
(\%)\end{array}$ & $\begin{array}{c}\mathrm{Ca} \\
(\%)\end{array}$ & $\begin{array}{c}\text { P } \\
(\%)\end{array}$ \\
\hline Jagung & $2785,32^{\mathrm{A}}$ & $10,92^{\mathrm{A}}$ & $4,85^{\mathrm{A}}$ & $2,20^{\mathrm{A}}$ & $0,37^{\mathrm{E}}$ & $0,23^{\mathrm{E}}$ \\
Bekatul & $2752,27^{\mathrm{A}}$ & $11,93^{\mathrm{A}}$ & $9,95^{\mathrm{A}}$ & $11,07^{\mathrm{A}}$ & $0,37^{\mathrm{E}}$ & $1,27^{\mathrm{E}}$ \\
Tepung Ikan & $2091,40^{\mathrm{A}}$ & $38,55^{\mathrm{A}}$ & $5,18^{\mathrm{A}}$ & $2,31^{\mathrm{A}}$ & $5,28^{\mathrm{D}}$ & $2,00^{\mathrm{B}}$ \\
Pollard & $2587,10^{\mathrm{A}}$ & $13,46^{\mathrm{A}}$ & $0,70^{\mathrm{A}}$ & $4,48^{\mathrm{A}}$ & $0,39^{\mathrm{E}}$ & $0,60^{\mathrm{E}}$ \\
Bungkil & $2985,05^{\mathrm{A}}$ & $50,02^{\mathrm{A}}$ & $3,00^{\mathrm{A}}$ & $1,90^{\mathrm{A}}$ & $0,32^{\mathrm{E}}$ & $0,29^{\mathrm{E}}$ \\
Kedelai & & & & & & \\
Premix & $959,00^{\mathrm{A}}$ & $5,26^{\mathrm{A}}$ & $4,23^{\mathrm{A}}$ & $3,53^{\mathrm{A}}$ & $3,30^{\mathrm{C}}$ & $3,50^{\mathrm{C}}$ \\
$\mathrm{CaCO}_{3}$ & - & - & - & - & $38,00^{\mathrm{D}}$ & - \\
\hline
\end{tabular}

Sumber A. Hasil Analisis Proksimat Laboratorium Ilmu Nutrisi Ternak, Fakultas Peternakan dan Pertanian, Universitas Diponegoro, 2016.

B. Hasil Analisis bahan pakan Universitas Muhammadiah Malang, 2014

C. Hasil Analisa Laboratorium Kimia, Universitas Negeri Semarang, 2015.

D. Hasil Analisis Proksimat di Laboratorium Ilmu Makanan Ternak,Fakultas Peternakan dan 
Pertanian, Universitas Diponegoro, 2012

E. Hasil Analisis Proksimat di Laboratorium Ekologi dan Produksi Tanaman Fakultas

Peternakan dan Pertanian, Universitas Diponegoro (Rahmawati dkk. 2016).

Tabel 3. Susunan Ransum dan Kandungan Nutrisi

\begin{tabular}{|c|c|c|c|c|}
\hline \multirow{2}{*}{ Bahan Pakan } & \multicolumn{4}{|c|}{ Ransum Perlakuan } \\
\hline & T0 & $\mathrm{T} 1$ & $\mathrm{~T} 2$ & T3 \\
\hline Jagung (\%) & 55 & 54,4 & 54,6 & 54,7 \\
\hline Bekatul (\%) & 15,3 & 12,5 & 12 & 9,1 \\
\hline Tepung Ikan (\%) & 5 & 3,5 & 3,5 & 3,5 \\
\hline Pollard (\%) & 11 & 7,7 & 4 & 3 \\
\hline Bungkil Kedelai (\%) & 12 & 10,2 & 9,2 & 8 \\
\hline $\mathrm{CaCO}_{3}$ & 0,7 & 0,7 & 0,7 & 0,7 \\
\hline Premix & 1 & 1 & 1 & 1 \\
\hline Tepung Azolla fermentasi & 0 & 10 & 15 & 20 \\
\hline Total $(\%)$ & 100 & 100 & 100 & 100 \\
\hline Kandungan Nutrien : & & & & \\
\hline Protein kasar $(\%)$ & 17,24 & 17,35 & 17,53 & 17,68 \\
\hline EM (kkal/kg) & 2709,97 & 2923,63 & 3028,82 & 3129,05 \\
\hline Serat kasar (\%) & 5,00 & 6,02 & 7,54 & 8,11 \\
\hline Lemak Kasar(\%) & 4,94 & 4,79 & 4,85 & 4,68 \\
\hline $\mathrm{Ca}(\%)$ & 0,90 & 0,96 & 1,02 & 1,08 \\
\hline $\mathrm{P}(\%)$ & 0,56 & 0,52 & 0,52 & 0,50 \\
\hline
\end{tabular}

Sumber: Tabel komposisi bahan makanan ternak, 2017.

\section{HASIL DAN PEMBAHASAN}

Pengaruh penggunaan tepung Azolla microphylla fermentasi terhadap bobot saluran pencernaan ayam kampung persilangan disajikan pada Tabel 4.

Tabel 4. Rata-rata Bobot Relatif Organ Saluran Pencernaan

\begin{tabular}{lcccc}
\hline \multicolumn{1}{c}{$\begin{array}{c}\text { Organ saluran } \\
\text { pencernaan }\end{array}$} & $0 \%$ & $10 \%$ & $15 \%$ & $20 \%$ \\
\cline { 2 - 4 } & \multicolumn{4}{c}{ Azolla microphylla } \\
Proventikulus & 0,60 & 0,68 & 0,58 & 0,65 \\
Ventrikulus & 3,24 & 3,24 & 2,75 & 2,67 \\
Usus halus : & & & & \\
Duodenum & 1,02 & 0,96 & 0,98 & 0,95 \\
Jejenum & 1,15 & 1,01 & 1,10 & 1,02 \\
Ileum & $0,92^{\mathrm{a}}$ & $0,93^{\mathrm{a}}$ & $0,76^{\mathrm{ab}}$ & $0,66^{\mathrm{b}}$ \\
Usus besar & 0,20 & 0,17 & 0,16 & 0,16 \\
Sekum & 0,55 & 0,47 & 0,49 & 0,48 \\
\hline Supersip & & &
\end{tabular}

Superskip yang berbeda pada baris yang sama menunjukkan perbedaan yang nyata $(\mathrm{P}<0,05)$

Tabel 5. Rata-Rata Panjang relatif Organ Saluran Pencernaan.

\begin{tabular}{lcccc}
\hline \hline \multirow{2}{*}{$\begin{array}{c}\text { Organ saluran } \\
\text { pencernaan }\end{array}$} & \multicolumn{4}{c}{ Azolla microphylla } \\
\cline { 2 - 4 } & $0 \%$ & $10 \%$ & $15 \%$ & $20 \%$ \\
\hline \multirow{2}{*}{ Duodenum } & 1,20 & 1,39 & 1,44 & 1,41 \\
Jejenum & 5,76 & 5,25 & 5,62 & 5,61
\end{tabular}




\begin{tabular}{lcccc}
\hline \multirow{2}{*}{$\begin{array}{c}\text { Organ saluran } \\
\text { pencernaan }\end{array}$} & \multicolumn{4}{c}{ Azolla microphylla } \\
\cline { 2 - 4 } Ileum & $0 \%$ & $10 \%$ & $15 \%$ & $20 \%$ \\
\hline Usus besar & 3,70 & 4,56 & 5,39 & 4,93 \\
Sekum & 0,76 & 0,57 & 0,77 & 0,73 \\
\hline
\end{tabular}

Superskip yang berbeda pada baris yang sama menunjukkan perbedaan yang nyata $(\mathrm{P}<0,05)$

Pengaruh Penggunaan Tepung Azolla microphylla fermentasi Terhadap Bobot Proventrikulus dan Ventrikulus

Penggunaan tepung Azolla

microphylla fermentasi tidak menunjukkan pengaruh terhadap persentase proventrikulus dan ventrikulus. Dalam penelitian ini, bobot proventrikulus lebih besar dari hasil penelitian Noferdiman (2012) menyatakan bobot relatif proventrikulus (ayam ras) berkisar antara $0,50-0,53 \%$. Hal ini diduga karena ransum yang diberikan tidak mengakibatkan peningkatan kinerja proventrikulus dalam mencerna pakan. Proventrikulus merupakan tempat terjadinya pencernaan secara enzimatis. Proses pencernaan makanan berjalan cepat dalam jangka waktu yang pendek di dalam proventrikulus, maka pencernaan pada material makanan secara enzimatis sedikit terjadi. Pendapat Tossaporn (2013) bahwa tidak ada pengaruh perbedaan serat kasar pada bobot proventrikulus. Suprijatna dkk (2005) menyatakan fungsi proventrikulus adalah pencernan kimiawi dan suatu pelebaran dari kerongkongan sebelum berhubungan dengan gizzard.

Dalam penelitian ini bobot ventrikulus lebih besar dari hasil penelitian Putnam (1991) dimana presentase bobot ventrikulus 1,6\%-2,3\% dari bobot hidup ayam kampung. Hasil ini sedikit besar dari hasil penelitian Ukim dkk (2012) bahwa kisaran bobot relatif ventrikulus (ayam ras) berkisar 2,07-2,31\%. Bobot ventrikulus dipengaruhi oleh aktivitas otot ventrikulus. Aktivitas otot ventrikulus akan terjadi apabila makanan masuk kedalam tubuh dan terjadi proses metabolisme. Proses metabolisme mempengaruhi aktivitas ventrikulus. Kandungan serat kasar ransum mencapai 7,25\% tidak membuat kontraksi otot ventrikulus bekerja keras untuk memecah partikel pakan yang berserat, sehingga bobot ventrikulus tidak memperlihatkan perbedaan yang nyata. Dalam hal ini tepung Azolla microphylla fermentasi memiliki kandungan serat kasar tinggi namun tidak menunjukkan pengaruh terhadap bobot ventrikulus. Menurut Rohmah dkk (2016), aktivitas kerja ventrikulus dan jenis pakan yang diberikan berpengaruh terhadap besar kecilnya bobot ventrikulus. Hal ini sama disebutkan oleh Murtidjo (2005) ventrikulus berfungsi sebagai penggiling makanan, terutama bijibijian yang telah dilumuri enzim pepsin.

\section{Pengaruh Penggunaan Tepung Azolla microphylla fermentasi Terhadap Bobot dan Panjang Usus halus, usus besar dan sekum}

Hasil analisis ragam menunjukkan bahwa penggunaan tepung Azolla microphylla fermentasi berpengaruh menurunkan bobot relatif ileum namun tidak berpengaruh terhadap bobot relatif duodenum, jejenum dan panjang relatif usus halus. Hal ini diduga karena nutrisi 
dalam tepung Azolla microphylla fermentasi memiliki serat kasar tinggi sehingga tidak dapat dicerna dan diserap di dalam usus halus (ileum) namun dapat dicerna di usus besar dan sekum. Ukuran usus halus berpengaruh pada kapasitas usus halus dalam mencerna dan menyerap zatzat makanan. Usus halus hanya mampu menghidrolisis karbohidarat sederhana untuk diserap tubuh sebagai sumber energi, sedangkan serat kasar tidak mampu didegradasi. Panjang usus halus tidak mengalami pemanjangan dan penebalan pada dindingnya ketika ditambahkan oleh pakan yang mengandung serat kasar yang mencapai $7,25 \%$. Pakan yang megandung serat kasar tinggi proses pencernaan menjadi lambat karena kerja enzim dalam menghidrolisis zat makanan lebih lama, sehingga penyerapan zat-zat makanan berjalan kurang efektif (Rohmah dkk, 2016). Hal ini sesuai dengan pendapat Scott dkk (1982), bahwa usus halus hanya mampu menghidrolisis karbohidrat sederhana untuk diserap dalam tubuh sebagai energi, sedangkan pada serat kasar tidak mampu didegradasi. Sebagian serat kasar hanya lewat dari usus halus dan dilanjutkan pada saluran pancernaan bagian akhir. Menurut Ressang (1986), fungsi usus halus sebagai tempat pencernaan enzimatis dan penyerapan zat makanan. Panjang usus bervariasi sesuai dengan bobot ayam dan jenis pakan.

Penggunaan tepung Azolla microphylla fermentasi tidak berpengaruh pada bobot relatif usus besar dan sekum namun meningkatkan panjang relatif sekum. Ransum yang diberikan tidak meningkatkan kenerja usus besar dalam menyerapan zat makanan terutama pada serat kasar. Aktivitas usus besar yang rendah menyebabkan rendahnya bobot dan panjang relatif usus besar. Sari (2012) menyatakan bahwa penyerapan serat kasar pada usus besar berlangsung dalam jumlah kecil, sehingga tidak ada pengaruh pada dalam peningkatan panjang usus besar ayam kampung. Menurut Gunawan (2011), usus besar berfungsi sebagai penyalur sisa makanan dari usus halus ke kloaka dan tempat terjadinya penyerapan air dan mineral.

Kandungan serat kasar pada pakan yang menggunakan tepung Azolla microphylla fermentasi sebesar 7,25\% menyebabkan mikroba selulolitik berkembang biak dalam sekum sehingga terjadi perubahan ukuran panjang sekum. Sesuai dengan pendapat Wahju (2004), pencernaan serat kasar di unggas terjadi pada sekum dengan bantuan mikroorganisme yang menyebabkan unggas tidak memiliki enzim selulasae yang dapat memecah serat kasar. Suprijatna (2010) menyatakan bahwa pencernaan serat kasar pada unggas yang terjadi pada sekum mencapat 20-30\%. Sekum merupakan saluran pencernaan yang berfungsi sebagai tempat proses fermentasi untuk memecah sarat kasar unggas. Semakin tinggi serat pada pakan, aktivitas mikroba sekum semakin meningkat menyebabkan dinding sekum semakin menebal. Menurut Kismono (1986), peningkatan kadar serat dalam pakan menyebabkan pertambahan panjang sekum karena terdapat kemampuan merenggang untuk mencerna pakan. Hass dkk (2014) menyatakan sekum berfungsi sebagai tempat pencernaan secara mikrobial untuk mencerna nutrien yang tidak diserap oleh usus halus khususnya serat dan nitrogen.

\section{KESIMPULAN}

Penggunaan tepung Azolla microphylla menurunkan bobot ileum dan meningkatkan panjang sekum saluran pencernaan ayam kampung persilangan. 
DAFTAR PUSTAKA

Gunawan. Y. 2011. Organ dalam ayam kampung umur 10 minggu yang diberi ransum mengandung bungkil biji jarak pagar (Jatropha curcas L) terfermentasi Rhizopus oligosporus. Fakultas Peternakan. Institut Pertanian Bogor. Bogor

Hass, H., A. Napirah dan A. Indi. 2014. Efek peningkatan serat kasar dengan penggunaan daun murbei dalam ransum broiler terhadap presentase bobot saluran pencernaan. JITRO 1 (1) 63-69.

Iyayi, E. A., O. Agunsola dan R. Ijaya. 2005. Effect of three sources of fibre and period of feeding on the performance, carcase measures, organ relative weight and meat qualitiy in broiler. International Journal Science 4 (9): 695-700.

Kismono, M. M. S. S. 1986. Toleransi ayam broiler terhadap kandungan sert kasar, serat detergent asam, lignin dan silika dalam ransum yang mengandung tepung daun alangalang. Disertasi. Institut Pertanian Bogor. Bogor

Murtidjo, B. A. 2005. Pedoman Meramu Pakan Unggas. Kanisius, Yogyakarta.

Noferdiman. 2012. Efek penggunaan Azolla microphylla fermentasi sebagai pengganti bungkil kedele dalam ransum terhadap bobot organ pencernaan ayam broiler. Jurnal Penelitian Universitas Jambi 4 (1) : 49 - 56.

Putnam, P. A. 1991. Hand Book of Animal Science. Academic Press, San Diego.

Ressang, A. A. 1986. Patologi Khusus Veteriner. Edisi ke-2. N. V. Percetakan Bali, Denpasar.
Rohmah, N., E. Tugiyanti dan Roesdiyanto. 2016. Pengaruh Tepung Daun Sirsak (Announa muricata L.) dalam Ransum terhadpa Bobot Usus, Pankreas dan Gizzard Itik Tegal Jantan. Jurnal Agripet 16 (2): 140146.

Ryanda, A. W. 2013. Respon Lemak Abdominal dan Saluran Pencernaan Ayam Kampung dan Ayam Arab Terhadap Ransum Berserat Kasar Tinggi dengan Daun Katuk. Fakultas Peternakan. Institut Pertanian Bogor. Bogor.

Sari, M. 2012. Pengaruh Tepung Kulit Pisang Uli (Musa paradisiaca L.) dalam Pakan terhadap Lemak Abdominal, Organ Dalam dan Saluran Pencernaan Ayam Arab. Fakultas Peternakan. Institut Pertanian Bogor.

Scott, M. L., M. C. Nesheim and R. J. Young. 1982. Nutrition of The Chicken. Dept of Poultry Science and Graduate School of Nutrition Cornell. University of Ithaca. New York.

Suprijatna, E. 2010. Strategi pengembangan ayam lokal bebasis sumber daya lokal dan berwawasan ligkungan. Prosiding Seminar Nasional Unggas Lokal ke IV 55-79.

Suprijatna, E., A. Umiyati, dan K. Ruhyat. 2005. Ilmu Dasar Ternak Unggas. Penebar Swadaya. Jakarta.

Tossaporn, I. 2013. Histological adaptations of the gastrointestinal tract of broilers fed diets containing insoluble fiber from rice hull meal . American Journal of Animal and Veterinary Sciences 8 (2): 79-88. 